\title{
Analysis of Sharing Economy Services: Initial Findings from Sharing Cities Sweden
}

\author{
Jan Markendahl ${ }^{1, *}$, Mohammad Istiak Hossain ${ }^{1}$, Kes Mccormick ${ }^{2}$, \\ Tove Lund ${ }^{3}$, Jon Möller ${ }^{4}$ and Philip Näslund ${ }^{5}$
}

${ }^{1}$ Royal Institute of Technology, Stockholm, Sweden

${ }^{2}$ International Institute for Industrial Environmental Economics, Lund University, Sweden

${ }^{3}$ City of Gothenburg, Sweden

${ }^{4}$ City of Stockholm, Sweden

${ }^{5}$ City of Umeå, Sweden

E-mail: janmar@kth.se; hossain7@kth.se; kes.mccormick@iiiee.lu.se;

tove.lund@kom.goteborg.se; jon.moller@stockholm.se; philip.naslund@umea.se

${ }^{*}$ Corresponding Author

Received 23 November 2018;

Accepted 30 November 2018

\begin{abstract}
In this paper, we analyze different types of sharing economy services. The sharing economy is a wide concept where many types of activities and services can be included. Overall we aim to identify recurrent patterns but also similarities and differences between different types of sharing services. We discuss a multitude of different services, e.g. car pools, bike pools, sharing of tools and equipment, sharing of land for farming, sharing of parking and homes, and co-working spaces. It is a mix of different set ups regarding if it is commercial or community driven, type of service provider, usage fee or for free, open or closed access.

We look into drivers for different types of actors to use different types of sharing. In addition we look into how sharing services are offered and the platform implications. We study a set of sharing services in cities in Sweden. Primary data is collected from interviews with providers of sharing services and representatives of cities. Using an existing framework, we look into
\end{abstract}

Journal of NBICT, Vol. 1, 239-260.

doi: 10.13052/nbjict1902-097X.2018.013

This is an Open Access publication. (c) 2018 the Author(s). All rights reserved. 
different types of "sharing economies", and the "close cousins" of on-demand economy, second-hand economy and product service economy. Using the characteristics "idle capacity", "temporal use", and "consumer to consumer" it is possible to distinguish cases not being typical sharing economy.

Second hand and recycling of goods is not about temporary use, while car and bike pools, car rental, co-working spaces are not about idle capacity, the resources are there in order to be borrowed or rented. Using an open service platform any resource, provider, or seller as well any seller/user/renter can connect to the service; examples are eBay, Hygglo, and GrowGothenburg. For bike and pools, car rental and co-working spaces any user can rent but the resources are closely related to the renting service, external resources cannot be connected to the platform.

Keywords: Sharing services, Sharing economy, Business models, Digital platforms.

\section{Introduction}

The sharing economy is a wide concept where many types of activities and services can be included. In this paper, we will discuss a multitude of different services, some examples are car pools, bike pools, sharing of tools and equipment, sharing of land for farming, sharing of parking and homes, and co-working spaces. There is a mix of different set ups regarding commercial or community driven, type of service provider, usage fee or for free, and open or closed access.

Different types of actors and stakeholders have different views on what can be included and not in the sharing economy [1]. Many questions arise about the nature of the sharing economy.

- Is AirBnB part of the sharing economy but the hotel business is not?

- Do car and bike pools belong to the sharing economy but car rental is not?

- Is joint ownership within a closed community part of the sharing economy?

- Are public libraries and access to parks and public art part of the sharing economy?

An array of initiatives and projects are emerging to investigate the sharing economy and better understand its characteristics and impacts. Still, widespread ambiguity and confusion still exists around the term "sharing 
economy". This type of confusion is highlighted by many researchers in the area, e.g. by Schor [1] "Coming up with a solid definition of the sharing economy that reflects common usage is nearly impossible", by Frenken et al. [2] "Discussions about the sharing economy lack clear definitions" and by Acquire et al. [3] "One of the rare points scholars agree on is how hard it is to define the sharing economy and to draw clear conceptual and empirical boundaries. The sharing economy has become a catch-all label with strong normative underpinnings".

In this paper, we study a number of sharing services from different perspectives. We will look into different types of sharing services in terms of market and service settings and supporting service platforms. We have a number of research questions and contribution areas. Overall, we want to identify recurrent patterns but also similarities and differences between different types of sharing services.

Hence, then main research question is as follows: "What patterns can we identify for different types of sharing economy services?" We also want to look into motivations and drivers for different types of actors to use different types of sharing. Hence, another research question is as follows: "What drivers can we identify for different types and patterns of sharing services?" And finally: "How is a specific sharing service offered?" The last question relates both to the business setting and platform solution.

The paper is organized in several sections. Section 2 contains related work where we focus on sharing economy frameworks and sharing platforms. Our data collection and analysis approach are described in Section 3 on methodology. In Section 4 on cases, we shortly describe different sharing services and initiatives. Analysis and discussion is found in Section 5 where we discuss within three areas; i) cities and sharing economy, ii) what to include in sharing economy and not, and iii) sharing in different business settings and the service platform implications. Conclusions are in Section 6.

\section{Related Work}

\section{General aspects of the sharing economy}

A plethora of articles discusses the sharing economy and the importance of digital platforms to create the value of sharing economy. In literature, sharing economy appeared with many associated terms and concepts like collaborative consumption [4], collaborative economy [5] or peer-to-peer 
economy [6]. Some researchers characterized the sharing economy as microworking economy [7]. Sharing economy is explained from the business standpoint in [1] and [8]. Others have discussed the business model of sharing economy $[9,10]$. Few papers looked into the users' intention to participate in the sharing economy $[11,12]$ where other articles focus on the regulatory and economic issues $[13,14]$.

\section{Frameworks for the sharing economy}

A review of the sharing economy literature is presented in [3] together with examples of both broad and narrow definitions of the sharing economy and also highlighting key hypotheses of what can be included or excluded. In [3] the authors also position the sharing economy as "resting on three foundational cores: (1) Access economy, (2) Platform economy, and (3) Community-based economy". Both definitions and drivers of sharing economy are discussed in [15] and also related research discussing sharing economy both from a macro-economic as well as from a micro-economic perspective. The proposed framework includes processes and service components of relevance for sharing service platforms.

Guidance on how to describe the sharing economy can be given by the examples of classification proposed by some researchers. From [1]: "Sharing economy activities fall into four broad categories: i) recirculation of goods, ii) increased utilization of durable assets, iii) exchange of services and iv) Sharing of productive assets". For our analysis in Section 5 we make use of the definition of sharing economy in [2]: "consumers granting each other temporary access to under-utilized physical assets ("idle capacity"), possibly for money". Typical goods that are being shared are cars, homes, tools and clothes. This idea is further developed in [16] where a framework is presented. The objective is "to better understand the sharing economy as being defined by three characteristics: consumer-to-consumer interaction, temporary access, and physical goods". The authors are quite clear about what they consider to be sharing and not.

- "Sharing is about consumer-to-consumer platforms and not about renting or leasing a good from a company (business-to-consumer). In the latter case we would speak of product-service economy, where a consumer gains access to a product whilst the service provider retains ownership. An example is car-rental".

- "Sharing is about consumers providing each other temporary access to a good, and not about the transfer of ownership of the good. Thus, the sharing economy does not include the second-hand economy". 
- "Sharing is about more efficient use of physical assets and not about private individuals delivering each other a service".

The framework presented in [16] is based on the above mentioned definition of sharing economy and in this paper this is related and compared to its "close cousins"; on-demand economy, second-hand economy and product service economy.

\section{Business and platform aspects of the sharing economy}

When it comes to the platform-based economy, the two-sided sharing platform is discussed in [17] including elaboration on the pricing strategies and the openness of the platforms. Others have pointed out the categorization of a sharing economy based on the openness of the sharing economy and sharing platforms [18, 19]. A recent review on digital platforms on sharing economy [20] provides a thorough view on sharing economy and digital platforms. The authors have reviewed many papers that cover sharing economy, business model and technical challenges. One key contribution is the analysis and description of the roles and affordances of sharing economy platforms, examples are matchmaking, trust building and managing transactions.

\section{Methodology}

\section{Data collection}

The data collection was conducted through a multi-step process with a mix of collection of primary and secondary data. The first step was a wide scan for sharing services and initiatives in Sweden, including discussions with representatives for the cities Stockholm, Gothenburg, Umeå and Malmö combined with reading, sharing service web gages and public government and consultancy reports on the sharing economy [21,22]. The second step of data collection was to perform semi-structured interviews with representatives for cities and local communities, Electricity ${ }^{1}$ in Hammarby Sjöstad and Collaborative economy in Gothenburg ${ }^{2}$. The questions were about drivers to look into sharing services, what types of sharing services that are most interesting and the role that the city or community can play. The final step was to do interviews with providers and/or developers of sharing services and platforms, these services are presented shortly in Section 4. The questions

\footnotetext{
${ }^{1}$ http://www.electricitystockholm.se/

${ }^{2}$ http://www.kollekogbg.se/
} 


\section{4}

Jan Markendahl et al.

to the service providers where about the start-up process, the motivation to launch the service, partners and partnerships and how the service platform is designed.

We also have participated in workshops on sharing economy and smart cities, e.g. Electricity Energy and logistics workshop, AIMday workshop on smart cities, and the IoT Sweden and Viable cities annual program conferences 2018. In total, we collected primary data from 20 different actors including cities, communities, companies or start-ups.

\section{Data analysis}

For the case descriptions we employ the structure in [1] using "four broad categories": recirculation of goods, increased utilization of durable assets, exchange of services and sharing of productive assets. We also add aspects as joint ownership and access to public assets. For the analysis of sharing cases, we use a three-step process. First we apply the framework proposed in [16] in order to highlight the sharing characteristics in terms of use of idle capacity, temporary access, and if the sharing is about goods or time \& skills. Next, we look into different types of "sharing economies", and the "close cousins" on-demand economy, second-hand economy and product service economy. Finally, we identify and discuss the key characteristics of sharing business and its implications for the service platforms. We also include findings of the drivers for cities to look into sharing services.

\section{Cases}

In this section, we present the different cases of sharing services where different resources are shared or re-used. All of these types or sharing has in common that a specific resource can be used by many people and/or that unused resources are made available to others. We also include sharing of public resources and spaces provided by cities or municipalities.

\subsection{Recirculating Goods and Material}

Here we include both recirculation of goods and material. Recirculation of goods is part of the second hand economy including both fully commercial business and municipality initiatives. We also include commercial sites for trading of goods, e.g. eBay or Blocket.se. Many Swedish municipalities run a form of second hand business called "Aterbruket", the goods is typically books, furniture, clothes, toys and tools. This type of initiative is usually run by the labour market department as support for unemployed people that 
needs training in order to entre or re-enter the labour market ${ }^{3}$. Recirculation of material like newspaper, paper, bottles, clothes and textiles is strongly supported by Swedish municipalities. According to Uppsala municipality two thirds of all recycled textiles is re-used ${ }^{4}$. Internally in City of Stockholm Stocket is a service for re-use of office equipment and furniture is re-used, it is a form of internal second hand store that also creates new jobs.

A commercial second hand business is Klädoteket in Gothenburg. Here you can rent fashion clothes (with laundry) using a subscription and doing the booking over a web shop. From their webpage: "By leasing our clothes and accessories you can expand your wardrobe in our virtual closet". ${ }^{5}$ Another initiative in many Swedish cities and municipalities is called "Fritidsbanken" This can be described as a public library but for lending of sport equipment. Private persons, organizations, and companies provide (give away) equipment that can be borrowed for free up to two weeks. This is usually organized by local sport organizations, the municipality, the Swedish church, etc. One motivation for municipalities to engage in this is the need to support low income families.

\subsection{Increasing the Utilization of Durable Assets}

\section{Car pools and car sharing}

Sun Fleet is a subscription-based car pool with Volvo cars as owner ${ }^{7}$. You can book a car for an hour, a day or a week and you have to return the car at the same parking lot where you picked it up. Currently Sun Fleet offer 1400 cars at 50 locations all over Sweden. With the car pools Car2Go and DriveNow you can pick up and leave the car at different locations. However, both these companies recently closed the operation in Stockholm. The American car pool ZipCar just started business in Stockholm together with the real-estate company Wallenstam. Similar to Sun Fleet you need to pick up and leave the car at the same spot. Currently it is only tenants living in Wallenstam properties that can use ZipCar. These customers do not have any monthly subscription fee, just the usage fee ${ }^{8}$.

\footnotetext{
${ }^{3}$ https://jobbcenter.uppsala.se/arbetsplatser-i-egen-regi/aterbruket/

${ }^{4}$ https://www.uppsalavatten.se/sv/hushall/avfall-och-atervinning/kallsortering/klader-ochtextilier/

${ }^{5}$ https://kladoteket.se/how-it-works/

${ }^{6}$ https://www.fritidsbanken.se/

${ }^{7}$ https://www.sunfleet.com/

${ }^{8}$ https://teknikveckan.com/nyheter/zipcar-etablerar-sig-i-sverige/
} 


\section{Jan Markendahl et al.}

We can also consider closed user groups where a number of families share one or more cars. An example is the test with Micro Car pool performed in Hammarby sjöstad with Hertz and Renault as partners. Here three families share one car, the booking is made using the Herts booking smartphone app, where only the families can access and book the car ${ }^{9}$. In this group, we also bring up car sharing where you offer and make use of empty seat(s) in your car. Examples are blablacar ${ }^{10}$ and samåkning.se ${ }^{11}$.

\section{Bike pools and bike renting}

Bike pools and bike renting can be identified in a number of different business settings. Below we provide three examples illustrating the different settings. $U$-bike.se is an initiative by Umeå municipality where you can rent electric cargo bikes ${ }^{12}$. You need to book the bike the very same day that you will use it, you cannot book the bike in advance. In order to use U-bike and make reservations you need to register using the service platform Triply. Triply is also used for the "locked bike garage" service offered in Umeå. The motivation for the municipality to support both of these initiatives is to increase usage of bikes and reduce travelling by car. Uppsala Cykelförening, $U C F$, ("Uppsala bike association") is a local movement that supports increased and more userfriendly use of bikes. UCF offers renting of bikes in the bike pool, a bike workshop and try to influence the local politicians. Membership fee is very low ( $5 €$ per year) and then you can "rent" a bike for free. Each bike is located at a "host" that is responsible for maintenance and the lending out process. You locate and book bikes using a web page with a map ${ }^{13}$. UCF also cooperates with facility owners ${ }^{14}$.

Another example is the EU-bike commercial service offered by the company Green Economy $\mathrm{AB}^{15}$. In Uppsala 1000 ordinary bikes are offered to the public. The business setup is that you register yourself, book and pay using a smartphone app. The app is used to unlock the bike and after usage, you leave the bike wherever it suits you.

\footnotetext{
${ }^{9}$ http://hammarbysjostad20.se/elbilspooltest/

${ }^{10} \mathrm{https} / / /$ blog.blablacar.com/about-us

${ }^{11} \mathrm{https} / / /$ www.samakning.se/

${ }^{12} \mathrm{https}: / /$ portal.triply.se/pool/1

${ }^{13}$ https://beta.ucf.se/fordon/

${ }^{14} \mathrm{https}: / /$ www.uppsalahem.se/bo-hos-oss/ditt-grona-boende/lana-en-el-lastcykel/

${ }^{15} \mathrm{https}: / /$ eubike.se/
} 


\section{Sharing and renting of tools and equipment}

Hygglo $^{16}$ is a service for renting things between private individuals. The service targets all Sweden and common objects are tools, light trucks, vans, trailers, boats, bikes and sport equipment. It costs nothing to advertise and you retain $80 \%$ of the amount at a rental. For those who rent, there are no costs or fees in addition to the rental price. All persons are identified with BankID. Hygglo offers secure payments using credit cards and the amount of a rental is reserved upon payment and is paid after the rental. All items are insured.

Another sharing service and platform is Delbar.se ${ }^{17}$. It is similar to Hygglo with features for announcing items and to connect people. Delbar.se is founded in Umeå and is present in northern Sweden.

\section{Sharing of space}

When it comes to sharing of space, we provide four examples for sharing of different types of un-used spaces. Garageplatsen ${ }^{18}$ is a service for renting and renting out parking space.The service platform includes announcing, support for digital agreements and payments. Ett tak två generationer ${ }^{19}$ ("One roof two generations") is a solution for shared living over generation boundaries where senior people can rent out existing spare spaces in their homes to students. Grow Gothenburg ${ }^{20}$ is an initiative and service that connects people interested in urban farming and finding farmland with available unused land. The service includes land from private persons, real-estate owners and municipalities. In addition, GrowGothenburg also organizes courses and events for people that want to learn more about farming. Hoffice.nu is a network making use of space that is underused during day time, i.e. homes. Hoffice.nu is creating free workspaces in combination with networking activities during the working day $^{21}$. A daily host is responsible for the access and organization of the day.

\subsection{Exchanging Services}

Using the Time Village community, you can share your skills and/or get help from other Time Village members ${ }^{22}$. Main areas of skills are languages,

\footnotetext{
${ }^{16}$ https://www.hygglo.se/

${ }^{17}$ https://www.delbar.se/

${ }^{18} \mathrm{https}: / /$ www.garageplatsen.se/

${ }^{19} \mathrm{http}: / /$ www.etttaktvå generationer.se/

${ }^{20} \mathrm{https}$ //growgbg.com/sv/

${ }^{21} \mathrm{http} / / /$ hoffice.nu/en/what-is-hoffice/

${ }^{22}$ https://timevillage.org/
} 
cooking, baking, learning sports or playing a musical instrument, photography, dancing and coaching. Also more service oriented skills can be shared, e.g. bicycle repair, dog sitting, car sharing or computer fixes. If you want to share your skill, post a help offer or search for a help request that fits your skill. If you need help, you can post a skill request or search among Villagers' skill offers and wait, or find a relevant skill offer and send a help request. Yepstr ${ }^{23}$ is an app-based marketplace for tasks like babysitting, garden-work and dogminding. As a user you create an account and announce your needs, Yepstr will then distribute your request to youngsters in the neighbourhood. The work task is booked and paid using the app. In addition to the compensation, the Yeps (young entrepreneurs) can build a resume with references and can grant access to benefits. We also want to mention initiatives like $\mathrm{IB}^{24}$ and "language cafés" ${ }^{25}$ where people share their time in order to help non-Swedes to improve their language skills.

\subsection{Sharing of Productive Assets}

In this group, we mention two cases of co-working spaces both can be called "office hotel". Here you can rent a desk or space both for short-term usage or renting for a week or months. Examples are GoTo10 ${ }^{26}$ in Hammarby sjöstad and Träkoja ${ }^{27}$ in Uppsala.

\subsection{Other Cases}

Besides the sharing cases that easily can be put in any of the categories according to [1] we also include cases of sharing in housing associations and access to public city resources. ElectriCITY is a citizen initiative in the district Hammarby sjöstad to reduce the climate footprint in cooperation with companies, researchers and City of Stockholm ${ }^{28}$. ElectriCITY provides support for housing associations by sharing knowledge and experiences, and by coordinating procurement and planning of heavy transport. An example is analysis of and advice for energy use to housing associations, the so-called eco-drive. Another initiative is Snyggt och tryggt ("Clean and safe") with

\footnotetext{
${ }^{23} \mathrm{https} / / /$ www.yepstr.com/foretaget/in-english

${ }^{24}$ http://www.bekantskaper.se/;

${ }^{25} \mathrm{https} / / /$ www.thenewbieguide.se/coffee-with-spark-please/

${ }^{26}$ https://www.goto10.se/

${ }^{27} \mathrm{http} / / /$ trakoja.com/eng/

${ }^{28} \mathrm{http}: / /$ hammarbysjostad20.se/?lang=en
} 
neighbourhood actions and collaboration with the city for cleaning, removing of graffiti and dialogue about usage of common areas. ${ }^{29}$

From a City of Stockholm perspective the open access to many of the public assets like libraries, sport centres, swimming halls are examples of sharing economy. For some years the City of Stockholm provided the smartphone app Upptäck Stockholm ${ }^{30}$ (Discover Stockholm) with information about public places, parks, where you can do sport activities, etc. The app was developed by the environment office at City of Stockholm with support of other administrations, e.g. culture, traffic, sports and also the city district administrations.

\section{Analysis and Discussion}

In this section we discuss cities and the sharing economy, how to categorize different forms of sharing economy, and sharing in different business and platform settings.

\subsection{Cities and the Sharing Economy}

Cities around the world have taken different approaches to the sharing economy, both looking into opportunities and challenges. Many large cities have had to deal with the challenges when platform companies like Airbnb and Uber have established themselves in the cities. In Sweden existing laws have regulated these challenges relatively well and would anyhow mainly be dealt with at the national level. Still, there is an ongoing global movement and emerging cooperation among cities who work under the umbrella "sharing cities" and in November 2018 more than 50 cities met at the Sharing Cities Summit in Barcelona to exchange experiences and which resulted in a Sharing Cities Declaration ${ }^{31}$. The interviews with representatives in Swedish city governments show mainly that their approach to the sharing economy has primarily been to explore its potential to reach the city's sustainability goals, such as decreasing environmental and climate impact from consumption and private cars, but also to stimulate access to goods and services from a socioeconomic perspective, where initiatives such as Fritidsbanken play a key role. A city can take several initiatives such as launching its own sharing services (eg. pools for bikes and cargo bikes) or mapping its own resources in order

\footnotetext{
${ }^{29} \mathrm{http} / / /$ sjostadsforeningen.se/2018/02/25/snyggt-tryggt-i-hammarby-sjostad/

${ }^{30} \mathrm{http} / / /$ www.stockholm.se/upptackstockholm

${ }^{31}$ www.share.barcelona/declaration
} 
to unlock idle capacity which many cities do by opening up land for urban farming to its citizens, or by opening up meeting rooms in municipal buildings to civil society organisations. Also, the wish to increase evening activities in office districts can results in support to second hand stores or bike community bike workshops.

In general, the interviews with city representatives give an overall picture of a positive attitude to sharing and initiatives to handle climate change. Another way for a city to stimulate the sharing economy is to facilitate the growth of local sharing initiatives in the city. One example is how the City of Gothenburg supports the Smart map ${ }^{32}$, which is a mapping of more than 100 sharing initiatives in the city. The aim is to visualize options for a more sustainable consumption to its citizens. In Stockholm, the city has started Klimatsmarta Stockholmare ${ }^{33}$ ("climate friendly Stockholm"). Here the city provides general advice on how you as a citizen can live more environmentally friendly and reduce your climate impact, including areas like local travels, smart living, cooking, biking [23].

\subsection{Sharing Economy and its Close Cousins}

We apply the framework for defining sharing services proposed by Frenken \& Schor [16] using the characteristics "Temporary use", "Idle capacity", sharing in a "consumer to consumer" setting and if the sharing considers "Physical goods" (or services). From Figure 1 we can conclude that some services, according to Frenken \& Schor, can be seen as sharing and some are not, a few services can be discussed. The reasons for including or excluding services in the group "sharing economy" is more clearly seen if we look into the close cousins "second hand economy", "Product-service economy" and "On demand economy". The result of this mapping is shown in Figure 2.

Almost all services consider temporary use and physical goods. Second hand services are excluded due to the fact that the ownership is transferred, i.e. no temporary use. All other services that are excluded do no not fulfil the requirements on "use of idle capacity" and "consumer to consumer" setting. Following Frenken and Schor all the services of the type "product service" consider "pools" where you can borrow or rent bikes, cars, clothes, "things" or office space. Hence, there is no "idle capacity". The capacity is there in order to be borrowed, rented or leased.

\footnotetext{
${ }^{32} \mathrm{http} / / /$ smartakartan.se/

${ }^{33} \mathrm{http}: / /$ www.stockholm.se/ByggBo/Leva-Miljovanligt/
} 


\begin{tabular}{|c|c|c|c|c|c|}
\hline Service & $\begin{array}{c}\text { Temporary } \\
\text { use }\end{array}$ & $\begin{array}{l}\text { Use of idle } \\
\text { capacity }\end{array}$ & $\begin{array}{c}\mathrm{C} 2 \mathrm{C} \\
\text { setting }\end{array}$ & $\begin{array}{c}\text { Physical } \\
\text { goods }\end{array}$ & \multirow{6}{*}{$\begin{array}{l}\text { Not sharing according } \\
\text { to Frenken \& Schor }\end{array}$} \\
\hline Klädoteket & Yes & No & No & Yes & \\
\hline Ebay, Blocket.se & No & No & No & Yes & \\
\hline Återbruket & No & No & No & Yes & \\
\hline Fritidsbanken & Yes & No & No & Yes & \\
\hline SunFleet, ZipCar & Yes & No & No & Yes & \\
\hline Ubike,UCF, EU-bike & Yes & No & No & Yes & \multirow{8}{*}{$\begin{array}{l}\text { Sharing according } \\
\text { to Frenken \& Schor }\end{array}$} \\
\hline Trakoja, GoTo10 & Yes & No & No & Yes & \\
\hline Hoffice & Yes & Yes & Yes & Yes & \\
\hline Delbar, Hygglo & Yes & Yes & Yes & Yes & \\
\hline Garageplatsen & Yes & Yes & Yes & Yes & \\
\hline GrowGothenburg & Yes & Yes & Partly & Yes & \\
\hline One roof two gen... & Yes & Yes & Yes & Yes & \\
\hline samåkning.se & Yes & Yes & Yes & Yes & \\
\hline Time village & Yes & No & Yes & No & \multirow{2}{*}{ Can be discussed } \\
\hline Yepstr, Instajobs & Yes & No & No & No & \\
\hline
\end{tabular}

Figure 1 Analysis of services using the framework by Frenken and Schor [16].

Finally, sharing dealing with services is not seen as sharing by Frenken and Schor, they consider it as being part of the "on demand economy". However, in this paper we will include them as sharing service due the fact that main idea is the use of "idle capacity" in the form of time and/or skills.

So far, we have excluded sharing in a housing association context from the discussion.In this case the sharing includes both joint usage of common resources like laundry rooms, bike rooms and other common spaces as well as sharing of knowledge and skills. In Hammarby sjöstad also joint procurement and ownerships is seen as a form of sharing. Although temporary use of physical goods may occur, using the framework by Frenken \& Schor it is not seen as sharing due the fact that it is neither any "idle capacity" nor "consumer to consumer" sharing. All resources and activities exist within closed groups. This will be further developed in the next section when we discuss openness of service platforms.

\subsection{Sharing Economy and Platform Settings}

We will apply a simple platform model for the sharing economy and it close cousins. Key concepts will be two-sided and single sided service platforms, open and closed usage and also the direction of exchange and transactions. We will start to compare doubled sided platforms in two settings. The doublesided platform connects offers and needs. We call one setting "buyer-seller" where eBay and Blocket are typical examples.

We call the other setting "consumer to consumer renting-renting out", here all services denoted "sharing economy" in Figure 2 can be included. These 


\begin{tabular}{|l|c|c|c|c|}
\hline Service & $\begin{array}{c}\text { Sharing } \\
\text { economy }\end{array}$ & $\begin{array}{c}\text { Second hand } \\
\text { economy }\end{array}$ & $\begin{array}{c}\text { Product-service } \\
\text { economy }\end{array}$ & $\begin{array}{c}\text { On demand } \\
\text { economy }\end{array}$ \\
\hline Klädoteket & & $\mathrm{X}$ & $\mathrm{X}$ & \\
\hline Ebay, Blocket.se & & $\mathrm{X}$ & & \\
\hline Återbruket & & $\mathrm{X}$ & & \\
\hline Fritidsbanken & & $\mathrm{X}$ & $\mathrm{X}$ & \\
\hline SunFleet, ZipCar & & & $\mathrm{X}$ & \\
\hline Ubike,UCF, EU-bike & & & $\mathrm{X}$ & \\
\hline Trakoja, GoTo10 & & & $\mathrm{X}$ & \\
\hline Hoffice & $\mathrm{X}$ & & & \\
\hline Delbar, Hygglo & $\mathrm{X}$ & & & \\
\hline Garageplatsen & $\mathrm{X}$ & & & \\
\hline GrowGothenburg & $\mathrm{X}$ & & & $\mathrm{X}$ \\
\hline One roof two gen... & $\mathrm{X}$ & & & $\mathrm{X}$ \\
\hline samåkning.se & $\mathrm{X}$ & & & \\
\hline Time village & $\mathrm{X}$ & & & \\
\hline Yepstr, Instajobs & $\mathrm{X}$ & & & \\
\hline
\end{tabular}

Figure 2 Mapping of service onto "sharing economy and its close cousins" using framework by Frenken and Schor [16].

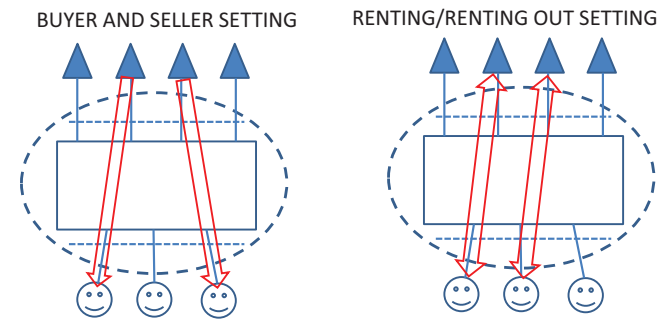

Figure 3 Resources and users in Buyer/Seller setting and Renting/Renting out setting.

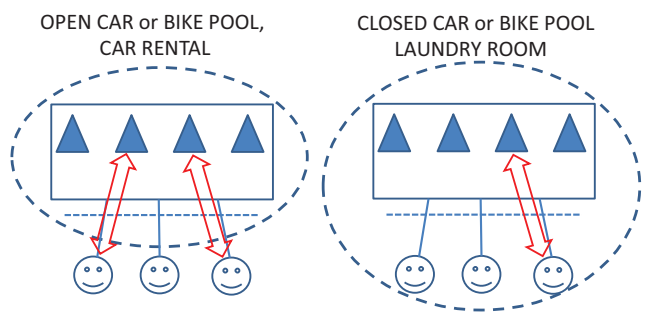

Figure 4 Resources and users for a single sided platform, open for anyone (left side). Resources and users for closed platform, both resources and users are internal (right side).

two settings are illustrated in Figure 3. The system under study consists of the service platform with its interfaces. Both sellers/providers and buyers/users are located outside the platform, anyone can connect. The difference is the temporary use for the sharing. 
We can compare the position of providers and users in two settings above with product-service economy and sharing in a housing association context. Car rental, carpools and co-working spaces are all examples of product-service economy. The resources are in a sense fixed and part of the platform. We call this a single sided platform, only users can connect. If we compare with shared resources in a housing association or in a private (closed) carpool both resources and users are located inside the system. No external users can access the resources.

\section{Comments on the applied framework}

One objective with this study is to identify recurrent patterns, similarities and differences between different types of services. We find both the framework and the key terms proposed by Frenken \& Schor [16] very well suited to describe and analyse the different cases of sharing discussed in this paper. Using the characteristics of "idle capacity", "temporal use", and "consumer to consumer" you can quite clearly distinguish cases not being typical of the sharing economy. Exchange in buyer-seller settings (e.g. Blocket.se) or recycling of goods is not about temporary use. Car pools, bike pools, car rental, co-working spaces are not about idle capacity, the resources are acquired in order to be borrowed or rented. As we see it, it does not matter if this is organized by a non-profit organisation or a commercial actor. Being less strict than Frenken \& Schor regarding physical goods we can also include sharing of time and skills (e.g. Time Village). Another aspect that highlights the temporary use of idle capacity, is that the exchange can be made (or is made) between strangers.

\section{Conclusions}

\section{Cities and the Sharing economy}

The interviews with city representatives provide insights on why different actors look into different types sharing initiatives. Overall, there is an ambition to increase awareness among citizens about climate change and how you can contribute. Another finding is that different initiatives cannot be studied in isolation; sharing services are often part of a bigger picture. As an example, recycling of goods and second hand activities can both create new jobs and support socially vulnerable families. A bike pool is one "component" if you want to reduce car traffic. 


\section{Research implications}

We have looked into how sharing services are offered or how sharing activities are organized. This leads to some conclusions about the business setting and the type of service platform used. We relax some of the characteristics of the framework proposed by Frenken \& Schor. By including (allowing) both i) physical goods and services and ii) business to consumer and consumer to consumer settings we can study many of the emerging sharing services using the same analysis framework.

\section{Platform implications}

We have also extended the framework by considering if the platform is open or closed for resources and users respectively. With a totally open two sided service platform any provider/seller as well any buyer/renter can connect to the service. Examples include eBAy, Blocket, Hygglo, Delbar, Grow Gothenburg and Garageplatsen. For bike pools, car pools, car rental and co-working spaces any user can rent a bike, car or office space. However, the resources are closely related to the renting service, other persons or companies cannot use the platform to offer their resources.

The level of openness is also relevant when discussing sharing in closed settings, for example a private car pool or sharing in housing associations, within an organization or company, within a family or among friends and neighbours. Here the activities often include joint ownership and usage of common resources, and coordination in order to improve efficiency and reduce costs of the common resources. In these cases, both the resources and users are within a closed community. Hence, it is not obvious what is meant with a sharing service or sharing platform in a closed setting. The term sharing economy implies some kind of offered service, some kind of business, exchange or transactions between a provider and user/renter. When both the provider and user side of the sharing platform are open for anyone then the meaning of "sharing" and a sharing service is more clear and concise.

\section{References}

[1] Schor, J. (2016). DEBATING THE SHARING ECONOMY. Journal of Self-Governance \& Management Economics, 4(3).

[2] Frenken, K., Meelen, T., Arets, M., and van de Glind, P. (2015). Smarter regulation for the sharing economy. The Guardian, 20. 
[3] Acquier, A., Daudigeos, T., and Pinkse, J. (2017). Promises and paradoxes of the sharing economy: An organizing framework. Technological Forecasting and Social Change, 125, 1-10.

[4] Botsman, R., and Rogers, R. (2011). What's mine is yours: how collaborative consumption is changing the way we live.

[5] Kostakis, V., and Bauwens, M. (2014). Network Society and Future Scenarios for a Collaborative Economy. Springer.

[6] Andersson, M., Hjalmarsson, A., and Avital, M. (2013). Peer-to-peer service sharing platforms: Driving share and share alike on a mass-scale.

[7] Cefkin, M., Anya, O., and Moore, R. (2014). A perfect storm? Reimagining work in the era of the end of the job. In Ethnographic Praxis in Industry Conference Proceedings (Vol. 2014, No. 1, pp. 3-19).

[8] Abdar, M., and Yen, N. Y. (2017, March). A Survey on Sharing Economy and Its Effect on Human Behavior Changes. In Advanced Information Networking and Applications Workshops (WAINA), 2017 31st International Conference on (pp. 99-103). IEEE.

[9] Daunoriene, A., Drakšaite, A., Snieska, V., and Valodkiene, G. (2015). Evaluating sustainability of sharing economy business models. ProcediaSocial and Behavioral Sciences, 213, 836-841.

[10] Munoz, P., and Cohen, B. (2017). Mapping out the sharing economy: A configurational approach to sharing business modeling. Technological Forecasting and Social Change, 125, 21-37.

[11] Lee, Z. W., Chan, T. K., Balaji, M. S., and Chong, A. Y. L. (2018). Why people participate in the sharing economy: an empirical investigation of Uber. Internet Research, 28(3), 829-850.

[12] Labrecque, L. I., vor dem Esche, J., Mathwick, C., Novak, T. P., and Hofacker, C. F. (2013). Consumer power: Evolution in the digital age. Journal of Interactive Marketing, 27(4), 257-269.

[13] Sundararajan, A. (2014). Peer-to-peer businesses and the sharing (collaborative) economy: Overview, economic effects and regulatory issues. Written testimony for the hearing titled The Power of Connection: Peer to Peer Businesses.

[14] Stewart, A., and Stanford, J. (2017). Regulating work in the gig economy: What are the options? The Economic and Labour Relations Review, 28(3), 420-437.

[15] Puschmann, T., and Alt, R. (2016). Sharing economy. Business \& Information Systems Engineering, 58(1), 93-99. 
[16] Frenken, K., and and Schor, J. (2017). Putting the sharing economy into perspective. Environmental Innovation and Societal Transitions, 23, 3-10.

[17] Rysman, M. (2009). The economics of two-sided markets. Journal of economic perspectives, 23(3), 125-43.

[18] Schor, J. B., Fitzmaurice, C., Carfagna, L. B., Attwood-Charles, W., and Poteat, E. D. (2016). Paradoxes of openness and distinction in the sharing economy. Poetics, 54, 66-81.

[19] Morell, M. F., and Espelt, R. (2018). How Much are Digital Platforms Based on Open Collaboration?: An analysis of technological and knowledge practices and their implications for the platform governance of a sample of 100 cases of collaborative digital platforms in Barcelona. In Proceedings of the 14th International Symposium on Open Collaboration (p. 26). ACM.

[20] Sutherland, W., and Jarrahi, M. H. (2018). The sharing economy and digital platforms: A review and research agenda. International Journal of Information Management, 43, 328-341.

[21] Government report, Delningsekonomi På användarnas villkor. SOU 2017:26.

[22] Report from IVL for Avfall Sverige. Dela prylar, yta, bil och tid - En vägledning till delningsekonomi i kommunerna. 2018:18.

[23] Gustafsson, U., and Simonsson, M. (2016). Klimatsmarta Stockholmare: En granskning av Stockholms stads klimatarbete utifrån ekologisk modernisering och ecological citizenship.

\section{Biographies}

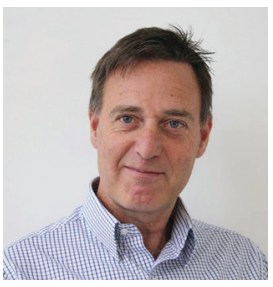

Jan Markendahl is Associate Professor in Wireless Infrastructure Deployment and Economics at Royal Institute of Technology (KTH), Stockholm. After more than 20 years in the industry Jan joined KTH 2003 
as research program manager. He has a $\mathrm{PhD}$ degree from 2011 in Technoeconomic analysis of wireless networks and services. Jan got the Docent degree 2014 enabling him to be main advisor for PhD students. So far three $\mathrm{PhD}$ and four Licentiate degrees have been awarded to his Phd students. Jan has managed techno-economic research projects and tasks in EU and national projects. He has made research contributions in the following areas: low cost wireless infrastructure, spectrum valuation, mobile payment and NFC services, IoT and M2M communication services and analysis of business models and ecosystems. Currently he works with business aspects of IoT, digital platforms, smart cities and sharing economy.

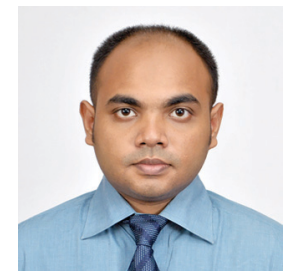

Mohammad Istiak Hossain is a Ph.D. student at the KTH Royal Institute of Technology, Stockholm, Sweden. He received his B.Sc. in Electronics and Telecommunication engineering from North South University, Bangladesh and MSc. degree in Electrical Engineering from the University of Applied Science Darmstadt, Germany. Hossain had held a system engineer position at NEC Laboratories Europe and worked as an enterprise network analyst at BRAC Bank, Bangladesh. He has been involved in Swedish and European projects together with in subjects related to SDN, NFV, IoT communications technologies, and 5G. His current research interests are in the areas of the Internet of Things and the economic implications of IoT services on IoT communication platforms. 


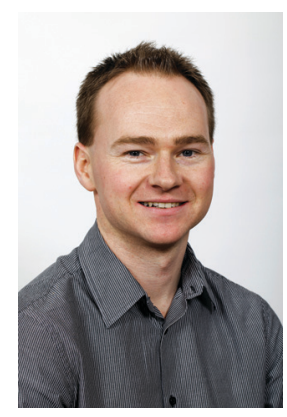

Kes McCormick works in the fields of sustainability, governance, cities and greening the economy. He is an Associate Professor at the International Institute for Industrial Environmental Economics (IIIEE) at Lund University, Sweden and an Honorary Fellow at the Melbourne Sustainable Society Institute (MSSI) at Melbourne University, Australia. He has participated in European, Swedish and Australian research and innovation projects, and since 2004, he has produced over 100 publications in a diversity of formats and presented at 50 international conferences. He is the program coordinator for Sharing Cities Sweden - a national program for the sharing economy in cities.

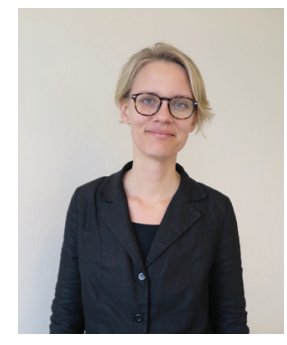

Tove Lund received her BA Hons in International relations and Human Geography from the University of Westminster, UK and a Master in political science at University of Lund, Sweden, in 2002. Ms Lund has worked in several positions at local governments in Sweden during the last 15 years. Since 2011, she works at the City of Gothenburg as a planning manager for sustainable consumption and with an interest in how the sharing economy can be a tool towards a more resource efficient consumption. Since 2017 she is the coordinator of the Urban Living lab Sharing City Gothenburg, where the city develops and evaluates sharing initiatives in the city. 


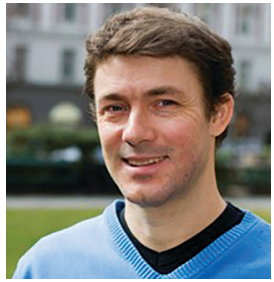

Jon Möller, works as Project Manager for the communication and citizen engagement team Climate Smart Stockholmers at the Environment and Health Administration in the City of Stockholm. He previously worked as Political Secretary with a Vice Mayor in the City Hall 2007-2008 and as Agenda 21 Co-ordinator of the City of Stockholm 1999-2006. Moller also worked as Researcher on sustainable consumption at the Department of Systems Ecology at the University of Stockholm 1996-1998. He received his B.A. in Environmental studies and Geography at Macalester College, Saint Paul, MN, USA in 1993.

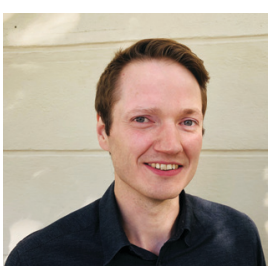

Philip Näslund is project manager for Sharing City Umeå at the City of Umeå. Philip has a bachelor's degree in Environmental Science, Linköping University. Philip is coordinator of the city of Umeå test-bed in the Swedish program Sharing Cities Sweden since 2018. City of Umeå contributes to the project by testing and evaluating the impact of the sharing economy in cities. Philip has previously been working as an Environmental Coordinator at the Region of Gävleborg and the County Council of Dalarna. 
